\title{
SUPERVISI YANG EFEKTIF DALAM PERSPEKTIF GURU MADRASAH ALIYAH NEGERI (MAN) DI KUDUS
}

\author{
Dani Hermawan \\ IAIN Jember \\ mbah.jarot@gmail.com
}

\section{DOI: https://doi.org/10.35719/jieman.v2i2.34}

\begin{abstract}
Abstrak
Penelitian ini bertujuan untuk mengkaji efektivitas pengawasan dari perspektif guru Madrasah Aliyah Negeri (MAN) di Kudus. Tujuan utama dari penelitian ini adalah untuk mengetahu efektivitas pengawasan yang berjalan di Madrasah Aliyah Negeri (MAN) di Kudus. Selain itu, penelitian ini juga mengkaji perspektif guru terhadap proses pengawasan Madrasah Aliyah Negeri (MAN) di Kudus. Selanjutnya, peneliti juga mengeksplorasi model pengawasan yang efektif berjalan di Madrasah Aliyah Negeri (MAN) di Kudus berdasarkan perspektif guru. Penelitian ini merupakan penelitian lapangan dengan metode campuran yang mengakomodasi kedua pendekatan kuantitatif dan kualitatif. Pengumpulan data menggunakan kuesioner untuk kuantitatif dan wawancara untuk kualitatif. Metode analisis data menggunakan survei untuk kuantitatif, dan komparatif konstan untuk kualitatif. Adapun lokasi penelitian sendiri di MAN 1 Kudus dan MAN 2 Kudus. Dari analisis data dapat diperoleh temuan penelitian sebagai berikut; pertama, proses pengawasan di Madrasah Aliyah Negeri (MAN) di Kudus berjalan secara efektif. Kedua, perspektif guru untuk proses pengawasan Madrasah Aliyah Negeri (MAN) di Kudus positif. Sedangkan yang ketiga, model pengawasan yang efektif berjalan di Madrasah Aliyah Negeri (MAN) di Kudus berdasarkan perspektif guru adalah Supervisi Klinis dan monitoring Administrasi.
\end{abstract}

Kata Kunci: pengawasan yang efektif, perspektif guru, model pengawasan

\section{Abstract \\ This study intends to look at the real phenomena of effective supervision from teachers' perspectives of Madrasah Aliyah Negeri (MAN) in Kudus.}


The purpose of this research is described as follows: to find out whether supervision runs in Madrasah Aliyah Negeri (MAN) in Kudus run effectively or not, to explain the teachers' perspectives to supervision process of Madrasah Aliyah Negeri (MAN) in Kudus, and to explore the model of supervision which effectively runs in Madrasah Aliyah Negeri (MAN) in Kudus based on the teachers'perspectives. This research is a field with mixed method that accommodate both of quantitative and qualitative approach. Collecting data using questionnaire for quantitative and interviews for qualitative. Methods of data analysis using survey for quantitative and constant comparative for qualitative. The location is in MAN 1 Kudus and MAN 2 Kudus. These research findings are; first, supervision process in Madrasah Aliyah Negeri (MAN) in Kudus runs effectively. Secondly, teachers'perspectives to supervision process of Madrasah Aliyah Negeri (MAN) in Kudus are positive. And the third, model of supervision which effectively runs in Madrasah Aliyah Negeri (MAN) in Kudus based on the teachers'perspectives is Clinical Supervision and Administrative monitoring.

Keywords: effective supervision, teachers' perspectives, supervision models

\section{Pendahuluan}

Supervisi dirancang untuk mempromosikan proses belajar mengajar yang efektif di sekolah. Kurangnya pengawasan dapat mengakibatkan kesiapan guru yang tidak memadai oleh sikap negatif siswa terhadap sekolah dan iklim sekolah yang tidak kondusif. ${ }^{1}$ Dalam kurun waktu yang lama, supervisi di Indonesia dilakukan berdasarkan prinsip hirarki. Peran guru adalah sebagai mediator untuk menyampaikan kebenaran dasar kepada anak-anak, sedangkan peran pengawas adalah memastikan kurikulum telah diikuti dan keterampilan penting telah dipelajari. Namun supervisi saat ini harus dilakukan secara efektif. Perlu keterlibatan semua pihak pada umumnya, pengawas dan pembimbing khususnya, ${ }^{2}$ sehingga supervisi yang efektif dapat menjadi kunci untuk memberikan hasil yang positif.

${ }^{1}$ Enamiroro Patrick Oghuvbu, Determinants of Effective and Ineffective Supervision in Schools: Teachers Perspectives (Winneba, Ghana: University of Education, 2015), 29-34.

${ }^{2}$ Andrea Rowe and Jane Haywood, Providing Effective Supervision Includes Examples for Organisations and Managers to Adapt for the Development of Their Supervision Practice. A Workforce Development Tool, Including a Unit of Competence and Supporting Guidance, This publication may be copied for noncommercial distribution in aid of workforce development (England: Skills for Care \& CWDC, 2007), 7 . 
Pendidikan adalah proses rumit yang membawa berbagai segi pandangan ke dalam proses pelaksanaannya. Peran seorang guru dalam proses ini tidak bisa dianggap remeh untuk memenuhi tujuan pendidikan dalam proses belajar mengajar. ${ }^{3}$ Pada saat yang sama, masing-masing guru mungkin memiliki cara yang berbeda dalam meningkatkan pengajaran di kelas dan sekolah. Mereka berada dalam posisi unik untuk memelihara, mengembangkan, dan mengartikulasikan pandangan masyarakat tentang seperti apa lingkungan belajar dapat dan seharusnya dikelola. ${ }^{4}$ Guru-guru di Indonesia memiliki perspektif sendiri tentang topik ini, supervisi yang efektif. Mereka berasal dari latar belakang pendidikan, lingkungan sosial dan tingkat ekonomi yang berbeda. Mereka juga memiliki latar belakang pengetahuan, sudut pandang dan pendidikan yang berbeda. Dengan mengetahui dan memahami perspektif mereka, pengelola, kepala sekolah, atau pengawas pendidikan dapat melihat bagaimana pandangan guru itu sendiri terhadap masalah ini.

Madrasah Aliyah Negeri (MAN) di Kudus merupakan dua sekolah (MAN o1 dan MAN o2) yang selalu menjalankan supervisi sebagai sarana untuk meningkatkan proses belajar mengajar serta pengembangan profesionalitas guru yang bekerja di lembaga tersebut. Pengelola MAN di Kudus sangat menyadari fungsi pengawasan. Hal tersebut umumnya dilakukan untuk mencapai visi dan misi sekolah, disamping secara khusus untuk meningkatkan kompetensi akademik dan manajerialnya. Berdasarkan Peraturan Pemerintah Nomor 19 Tahun 2005 tentang Standar Nasional Pendidikan pasal 57, pengawasan meliputi: manajerial dan akademik dilakukan secara teratur dan terus menerus oleh supervisor, inspektur dan kepala sekolah. Ini juga digunakan untuk mengontrol proses pendidikan di sekolah yang diubah ke arah lain dan menjauhi jalurnya. Sekolah-sekolah tersebut harus menerapkan peraturan itu agar pengawasannya efektif.

Berdasarkan rangkaian penjalasan di atas, tujuan penelitian ini adalah: (1) untuk mengetahui apakah supervisi yang dijalankan di MAN di Kudus berjalan efektif atau tidak, (2) untuk menjelaskan perspektif guru MAN di Kudus terhadap proses supervisi yang

${ }^{3}$ Sean Smith, "Teacher Mentoring and Collaboration," Teacher Education Associate Editor's Column, Winter, 17, no. 1 (2020): 47-48.

${ }^{4}$ Thomas J. Sergiovanni, Robert J. Starratt, and Vincent Cho, Supervision: A Redefinition, NINTH EDITION (New York, NY: McGraw-Hill, 2014). 
efektif, dan (3) untuk mengeksplorasi model supervisi yang efektif berdasarkan perspektif guru MAN di Kudus.

Praktik supervisi pendidikan secara instruksional tampaknya menjadi masalah yang diperdebatkan dalam lingkaran pendidikan kontemporer, dan telah ditandai dengan pergeseran sikap di antara peneliti dan pendidik. Sergiovanni and Starratt ${ }^{5}$ menyatakan bahwa sekolah kontemporer perlu memberikan pilihan kepada guru dalam pendekatan supervisi. Serangkaian pendekatan mungkin berbeda untuk guru pemula dan yang berpengalaman.

Kajian berikut membedakan antara model tradisional dan alternatif untuk supervisi yang dapat dianggap paling efektif untuk pengembangan staf dan efektivitas guru. Ini termasuk supervisi klinis, pendekatan perkembangan, pengembangan kolaboratif, pengembangan mandiri atau reflektif, portofolio, dan rencana pertumbuhan profesional. Pemantauan administratif termasuk dalam tinjauan, tetapi tidak dapat dianggap sebagai pilihan bagi guru. Penerapan model praktik supervisi yang berbeda dimaksudkan tidak hanya untuk memberikan pilihan kepada guru; itu juga dirancang untuk memberikan pilihan kepada administrator dan sekolah.

Efektivitas berasal dari kata "efektif" yang berarti "efek" (Tidak ada akibatnya, pengaruh, kesan), ${ }^{6}$ sedangkan efektivitas sarana menunjukkan tingkat pencapaian suatu tujuan. Efektivitas menunjukkan keberhasilan yang dicapai dalam hal ditentukan atau tidaknya target atau sasaran. ${ }^{7}$ Hasil yang semakin mendekati target berarti semakin efektif. Pengawasan yang efektif adalah kunci untuk memberikan hasil yang positif bagi semua orang yang menggunakan perawatan sosial orang dewasa dan anak-anak, seperti sekolah, kantor, dan lain-lain. ${ }^{8}$ Oleh karena itu, semua organisasi perlu membuat komitmen yang positif dan tidak ambigu terhadap budaya pengawasan yang kuat.

Pengembangan profesionalitas merupakan komponen penting dari pendidikan guru yang berkelanjutan dan penting bagi

${ }^{5}$ Thomas J. Sergiovanni, The Principalship: A Reflective Practice Perspective (Boston: Allyn and Bacon, 1987), 49.

${ }^{6}$ W. J. S. Poerwadarminta, Kamus Umum Bahasa Indonesia, Ed. 3 (Jakarta: Balai Pustaka, 2003), 266.

7 Adrian Eley and Roy Jennings, Effective Postgraduate Supervision. (Maidenhead: McGraw-Hill International (UK) Ltd., 2007), https://public.ebookcentral.proquest.com/choice/publicfullrecord.aspx?p=28781.

8 Thelbert L. Drake and William Henry Roe, The Principalship, 5th ed (Upper Saddle River, N.J: Merrill, 1999), 7. 
peran staf sekolah ${ }^{9}$. Perkembangan ini berkaitan dengan peningkatan metode instruksional guru, kemampuan mereka untuk menyesuaikan instruksi untuk memenuhi kebutuhan siswa, dan keterampilan manajemen kelas mereka; dan dengan membangun budaya profesional yang bergantung pada keyakinan bersama tentang pentingnya pengajaran dan pembelajaran dan yang menekankan kolegialitas guru. Supervisi instruksional, dengan penekanan pada kemitraan dan peningkatan profesional, merupakan alat penting dalam membangun program pengembangan profesional yang efektif. ${ }^{10}$

Seorang guru (juga disebut guru sekolah atau, dalam beberapa konteks, seorang pendidik) adalah orang yang membantu orang lain untuk memperoleh pengetahuan, kompetensi atau nilai. Secara informal, peran guru dapat diambil oleh siapa saja (misalnya saat menunjukkan kepada kolega bagaimana melakukan tugas tertentu). ${ }^{11}$ Di beberapa negara, mengajar kaum muda usia sekolah dapat dilakukan dalam suasana informal, seperti di dalam keluarga, (homeschooling) daripada dalam pengaturan formal seperti sekolah atau perguruan tinggi. Di kebanyakan negara, pengajaran formal biasanya dilakukan oleh guru profesional yang dibayar. Penjelasan ini berfokus pada mereka yang bekerja, sebagai peran utama mereka, untuk mengajar orang lain dalam konteks pendidikan formal, seperti di sekolah atau tempat lain untuk pendidikan atau pelatihan formal awal.

Sementara perspektif itu sendiri adalah sudut pandang seseorang atau bagaimana seseorang berperilaku terhadap suatu fenomena atau kejadian masalah. Perspektif merupakan suatu cara pandang atau wawasan seseorang dalam menilai masalah yang terjadi di sekitarnya. Jadi perspektif merupakan cara pandang yang bersumber dari kesadaran seseorang terhadap suatu isu yang terjadi. Perspektif dapat digunakan sebagai penambah wawasan atau pengetahuan seseorang agar dapat melihat segala sesuatu yang

9 Zachariah Wanzare and Jose L da Costa, "Supervision and Staff Development: Overview of the Literature," Sage Publications, Nassp Bulletin, 84, no. 618 (October 2000): 47-54.

10 Zachariah Wanzare, "Educational Management Administration \& Leadership," Sage Publications, Educational Management Administration \& Leadership, 40, no. 2 (March 2012): 188-216.

${ }^{11}$ W. J. S. Poerwadarminta, Kamus Umum Bahasa Indonesia, Ed. 3 (Jakarta: Balai Pustaka, 2003), 345. 
terjadi dengan pandangan yang luas. ${ }^{12}$ Perspektif memiliki ciri-ciri seperti: seseorang yang memiliki cara pandang yang tinggi akan berpikir secara luas dan tidak mendiskriminasi sesuatu, sehingga tidak memandang satu hal dari sudut pandang yang sempit dan terfragmentasi, seseorang yang memiliki cara pandang yang tinggi akan mudah menjadi mampu berinteraksi dengan orang lain secara harmonis, seseorang yang memiliki sudut pandang lebih tinggi mampu bersaing atau berkompeten secara sehat.

Desain penelitian ini adalah mixed method convergence design dengan pengumpulan dan analisis data kuantitatif dan kualitatif. Creswell menjelaskan bahwa metode campuran adalah penelitian yang menggambarkan suatu fenomena yang melibatkan penggabungan atau integrasi data penelitian kualitatif dan kuantitatif dalam suatu studi penelitian. ${ }^{13}$ Artinya, penelitian ini mendeskripsikan supervisi yang efektif dari perspektif guru MAN di Kudus.

Alasan mengapa peneliti menggunakan desain penelitian ini tidak hanya mendeskripsikan data dengan menggunakan metode kuantitatif dan kualitatif, tetapi juga beralih ke konvergensi sistematis database dari kedua metode tersebut ${ }^{14}$. Convergence berarti titik penemuan dari dua atau lebih sumber. Hal ini dilakukan agar data yang dikumpulkan menjadi lebih valid dan meminimalisir kesalahan yang mungkin terjadi selama penelitian ini dilakukan, membandingkan berbagai perspektif yang dikumpulkan dari data kuantitatif dan kualitatif, serta menjelaskan hasil kuantitatif dengan menindaklanjuti data kualitatif. Sehingga, ide integrasi dalam berbagai jenis desain penelitian muncul.

Penelitian ini dilakukan di dua sekolah di kota Kudus. Pertama adalah MAN or Kudus, terletak di Jalan Conge, Desa Ngembalrejo, Kecamatan Mejobo. Populasinya sangat besar. Ada sekitar 4000 siswa pada tahun akademik ini. Jumlah guru 64 orang. Kemudian yang kedua adalah MAN o2 Kudus, terletak di desa Prambatan Kidul, Kecamatan Kaliwungu. Populasinya sangat besar. Ada sekitar 6000 siswa pada tahun ajaran ini. Guru berjumlah 72 orang.

${ }^{12}$ James H. Stronge, Qualities of Effective Teachers, 2nd ed (Alexandria, Va: Association for Supervision and Curriculum Development, 2007), 1-198.

${ }^{13}$ John W Creswell, A Concise Introduction to Mixed Methods Research (London: SAGE, 2014).

${ }^{14}$ John W. Creswell, Research Design: Qualitative, Quantitative, and Mixed Methods Approaches, 4th ed (Thousand Oaks: SAGE Publications, 2014). 


\section{Pembahasasan}

Bagian pertama dari bab ini menyajikan temuan dari kuesioner. Dimulai dengan informasi latar belakang (data demografi) responden. Demografi yang dicari adalah jenis kelamin, kelompok umur, status pekerjaan, jumlah tahun pengalaman menjadi guru MAN di Kudus. Bagian ini juga menanyakan responden tentang posisi mereka (Guru). Hal tersebut dapat dilihat pada tabel di bawah ini.

Tabel 1. Data Demografi Responden

\begin{tabular}{|c|c|c|c|c|c|}
\hline \multirow[t]{2}{*}{ Tema } & & \multicolumn{2}{|c|}{$\begin{array}{c}\text { Banyaknya Responden } \\
\text { (Guru) }\end{array}$} & \multirow[t]{2}{*}{$\begin{array}{c}\text { Jumlah } \\
\left(\sum\right)\end{array}$} & \multirow[t]{2}{*}{$\begin{array}{c}\text { Persentase } \\
(\%)\end{array}$} \\
\hline & & MAN 1 & MAN 2 & & \\
\hline \multirow{2}{*}{ Jenis Kelamin } & Laki-laki & 30 & 42 & 72 & 55,4 \\
\hline & Perempuan & 30 & 28 & 58 & 44,6 \\
\hline \multirow[t]{5}{*}{ Usia } & $\leq 25$ & 2 & 0 & 2 & 1,5 \\
\hline & $26-35$ & 7 & 26 & 33 & 25,4 \\
\hline & $36-45$ & 20 & 23 & 43 & 33,1 \\
\hline & $46-55$ & 26 & 20 & 46 & 35,4 \\
\hline & $\geq 56$ & 6 & 0 & 6 & 4,6 \\
\hline \multirow{2}{*}{$\begin{array}{l}\text { Status } \\
\text { Kepegawaian }\end{array}$} & PNS & 47 & 50 & 97 & 74,6 \\
\hline & Non-PNS & 13 & 20 & 33 & 25,4 \\
\hline \multirow{8}{*}{$\begin{array}{l}\text { Pengalaman } \\
\text { sebagai Guru }\end{array}$} & Tahun Pertama & 3 & 0 & 3 & 2,3 \\
\hline & $1-5$ & 4 & 2 & 6 & 4,6 \\
\hline & $6-10$ & 8 & 19 & 27 & 20,8 \\
\hline & $11-15$ & 17 & 23 & 40 & 30,8 \\
\hline & $16-20$ & 12 & 13 & 21 & 16,2 \\
\hline & $21-25$ & 8 & 10 & 22 & 16,9 \\
\hline & $26-30$ & 4 & 2 & 6 & 4,6 \\
\hline & $\geq 31$ & 4 & 1 & 5 & 3,8 \\
\hline \multirow{8}{*}{$\begin{array}{l}\text { Pengabdian di } \\
\text { MAN }\end{array}$} & Tahun Pertama & 3 & 1 & 4 & 3,1 \\
\hline & $1-5$ & 8 & 2 & 10 & 7,7 \\
\hline & $6-10$ & 12 & 22 & 34 & 26,2 \\
\hline & $11-15$ & 18 & 25 & 43 & 33,1 \\
\hline & $16-20$ & 10 & 8 & 18 & 13,8 \\
\hline & $21-25$ & 8 & 11 & 19 & 14,6 \\
\hline & $26-30$ & 0 & 1 & 1 & 0,8 \\
\hline & $\geq 31$ & 1 & 0 & 1 & 0,8 \\
\hline
\end{tabular}

Kuesioner diberikan kepada 136 calon responden (Guru). Seratus tiga puluh $(96 \%)$ responden mengembalikan kuesioner dan hanya $4 \%$ yang tidak menyerahkan. Hal itu terjadi karena mereka sedang sakit (tidak hadir), cuti hamil dan keluar kota. Tabel 1 menunjukkan bahwa 
responden sebagian besar adalah laki-laki (55,4\%), sedangkan perempuan $44,6 \%$. Selanjutnya, usia guru yang dominan berkisar antara 46 hingga 55 tahun $(35,4 \%)$. Ada perbedaan tipis dengan guru yang berumur 36 sampai 45 tahun $(33,1 \%)$. Hal ini juga menunjukkan bahwa mayoritas responden adalah pegawai negeri $(74,6 \%)$ sedangkan Non PNS $25,4 \%$. Setelah itu, sebagian besar responden $(30,8 \%)$ memiliki pengalaman menjadi guru selama 11 sampai 15 tahun sedangkan sebagian kecil memiliki tahun pertama $(2,3 \%)$ dan lebih dari 31 tahun $(3,8 \%)$. Ini sejalan dengan responden tertinggi yang berdedikasi dalam mengajar siswa MAN adalah 11 sampai 15 tahun $(33,1 \%)$, sedangkan yang terendah adalah 26 sampai 30 tahun dan lebih dari 31 tahun $(0,8 \%)$.

Bagian kedua dari kuesioner termasuk 8 item skala tentang efektivitas supervisi (kriteria dan praktik). Kuesioner dibagi menjadi sisi kiri (lembar "A") dan sisi kanan (lembar "B"). Untuk setiap item, guru diminta untuk memilih, di sisi kiri, "Ya" atau "Tidak" untuk membuat deskripsi yang jelas tentang setiap kriteria pengawasan yang efektif, dan di sebelah kanan, untuk menunjukkan bagaimana mereka mengalami kriteria tertentu pengawasan efektif di sekolah masing-masing, tingkat kesepakatan mereka tentang bagaimana mereka pikir itu harus dipraktikkan. Tanggapan di sisi kanan kuesioner disusun dalam kontinum dari "Rendah" ke "Tinggi" masing-masing.

Tabel 2. Efektifitas Supervisi MAN di Kudus

\begin{tabular}{|c|c|c|c|c|c|c|c|}
\hline \multirow[t]{2}{*}{ No } & \multirow{2}{*}{$\begin{array}{l}\text { PERNYATAAN } \\
\text { (Kriteria Supervisi } \\
\text { yang Efektif) }\end{array}$} & \multirow[t]{2}{*}{ A } & \multicolumn{3}{|c|}{ B } & \multirow{2}{*}{$\begin{array}{c}\text { Jmlh. } \\
(\Sigma)\end{array}$} & \multirow{2}{*}{$\begin{array}{c}\text { Pers. } \\
(\%)\end{array}$} \\
\hline & & & & $\mathrm{MAN}_{1}$ & MAN 2 & & \\
\hline \multirow[t]{4}{*}{ a. } & \multirow{4}{*}{$\begin{array}{l}\text { Supervisi yang } \\
\text { dilakukan di Pesantren } \\
\text { saya sendiri memiliki } \\
\text { aturan, mekanisme } \\
\text { dan kriteria yang jelas }\end{array}$} & \multicolumn{2}{|c|}{ Jawaban "Tidak" } & 5 & 2 & 7 & 5,4 \\
\hline & & Jawaban & Rendah & 5 & 2 & 7 & 5,4 \\
\hline & & "Ya” & Sedang & 35 & 21 & 56 & 43,1 \\
\hline & & & Tinggi & 15 & 45 & 60 & 46,1 \\
\hline \multirow[t]{4}{*}{ b. } & \multirow{4}{*}{$\begin{array}{l}\text { Supervisor tidak hanya } \\
\text { menilai, tetapi juga } \\
\text { membimbing dan } \\
\text { melatih saya yang } \\
\text { menjadi sasaran } \\
\text { pengawasan }\end{array}$} & \multicolumn{2}{|c|}{ "Jawaban "Tidak" } & 8 & 4 & 12 & 9,2 \\
\hline & & Jawaban & Rendah & 5 & 2 & 7 & 5,4 \\
\hline & & "Ya" & Sedang & 35 & 35 & 70 & 53,8 \\
\hline & & & Tinggi & 12 & 29 & 41 & 31,6 \\
\hline \multirow[t]{4}{*}{ c. } & \multirow{4}{*}{$\begin{array}{l}\text { Saya selalu } \\
\text { mendapatkan contoh / } \\
\text { bimbingan dari } \\
\text { pimpinan / senior di } \\
\text { Sekolah saya }\end{array}$} & \multicolumn{2}{|c|}{ Jawaban "Tidak" } & 5 & 3 & 8 & 6,2 \\
\hline & & Jawaban & Rendah & 2 & 2 & 4 & 3,1 \\
\hline & & "Ya" & Sedang & 43 & 31 & 74 & 56,9 \\
\hline & & & Tinggi & 9 & 35 & 44 & 33,8 \\
\hline \multirow[t]{4}{*}{ d. } & \multirow{4}{*}{$\begin{array}{l}\text { Supervisi yang } \\
\text { dilakukan di sekolah } \\
\text { saya dilakukan secara } \\
\text { obyektif oleh }\end{array}$} & \multicolumn{2}{|c|}{ Jawaban “Tidak" } & 5 & 3 & 8 & 6,2 \\
\hline & & Jawaban & Rendah & 2 & 3 & 5 & 3,8 \\
\hline & & "Ya" & Sedang & 41 & 28 & 69 & 53,1 \\
\hline & & & Tinggi & 12 & 36 & 48 & 36,9 \\
\hline
\end{tabular}




\begin{tabular}{|c|c|c|c|c|c|c|c|}
\hline \multirow[t]{2}{*}{ No } & \multirow{2}{*}{$\begin{array}{c}\text { PERNYATAAN } \\
\text { (Kriteria Supervisi } \\
\text { yang Efektif) }\end{array}$} & \multirow[t]{2}{*}{$\bar{A}$} & \multicolumn{3}{|c|}{$\mathrm{B}$} & \multirow{2}{*}{$\begin{array}{c}\text { Jmlh. } \\
(\Sigma)\end{array}$} & \multirow{2}{*}{$\begin{array}{c}\text { Pers. } \\
(\%)\end{array}$} \\
\hline & & & & \multirow[t]{2}{*}{$\mathrm{MAN}_{1}$} & \multirow[t]{2}{*}{$\overline{\text { MAN }_{2}}$} & & \\
\hline & pembimbing & & & & & & \\
\hline \multirow[t]{4}{*}{ e. } & \multirow{4}{*}{$\begin{array}{l}\text { Supervisi dilakukan; } \\
\text { memantau kondisi } \\
\text { nyata, aktual dan } \\
\text { sasaran perkembangan } \\
\text { kondisi pengawasan }\end{array}$} & \multicolumn{2}{|c|}{ Jawaban "Tidak" } & 6 & 5 & 11 & 8,4 \\
\hline & & Jawaban & Rendah & 4 & 2 & 6 & 4,6 \\
\hline & & "Ya” & Sedang & 43 & 30 & 73 & 56,2 \\
\hline & & & Tinggi & 7 & 33 & 40 & 30,8 \\
\hline \multirow[t]{4}{*}{ f. } & \multirow{4}{*}{$\begin{array}{l}\text { Supervisi dilakukan } \\
\text { secara rutin, } \\
\text { terstruktur dan } \\
\text { terencana dengan baik }\end{array}$} & \multicolumn{2}{|c|}{ Jawaban "Tidak" } & 5 & 3 & 8 & 6,2 \\
\hline & & Jawaban & Rendah & 4 & 3 & 7 & 5,4 \\
\hline & & "Ya" & Sedang & 39 & 28 & 67 & 51,5 \\
\hline & & & Tinggi & 12 & 36 & 48 & 36,9 \\
\hline \multirow[t]{4}{*}{ g. } & \multirow{4}{*}{$\begin{array}{l}\text { Supervisi yang } \\
\text { dilaksanakan di } \\
\text { Pesantren saya } \\
\text { dilakukan secara } \\
\text { teratur dan } \\
\text { menyeluruh } \\
\text { (komprehensif) }\end{array}$} & \multicolumn{2}{|c|}{ Jawaban "Tidak" } & 9 & 3 & 12 & 9,2 \\
\hline & & Jawaban & Rendah & 4 & 3 & 7 & 5,4 \\
\hline & & "Ya" & Sedang & 41 & 38 & 79 & 60,8 \\
\hline & & & Tinggi & 6 & 26 & 32 & 24,6 \\
\hline \multirow[t]{4}{*}{ h. } & \multirow{4}{*}{$\begin{array}{l}\text { Hasil supervisi } \\
\text { dilakukan dengan baik } \\
\text { dilaporkan dan } \\
\text { diinventarisasi }\end{array}$} & \multicolumn{2}{|c|}{ Jawaban “Tidak” } & 5 & 4 & 9 & 6,9 \\
\hline & & Jawaban & Rendah & 3 & 2 & 5 & 3,8 \\
\hline & & "Ya" & Sedang & 38 & 24 & 62 & 47,7 \\
\hline & & & Tinggi & 14 & 40 & 54 & 41,6 \\
\hline
\end{tabular}

Dari data yang terkumpul dapat diketahui bahwa jawaban responden adalah; 5,4\% jawaban "TIDAK" dan 94,6\% jawaban "YA" untuk kriteria pengawasan efektif pertama, 9,2\% "TIDAK" dan 90,8\% "YA" untuk kriteria kedua, 6,2\% "TIDAK" Dan 93,8\% "YA" untuk kriteria yang ketiga, 6,2\% "TIDAK" dan 93,8\% "YA" untuk kriteria yang keempat, 8,4\% "TIDAK" dan 91,6\% "YA" untuk kriteria yang kelima, 6,2\% "TIDAK" dan 93,8\% "YA" untuk kriteria keenam, 9,2\% "TIDAK" dan 90,8\% "YA" untuk kriteria ketujuh dan 6,9\% "TIDAK" dan 93,1 \% "YA" untuk kriteria yang terakhir.

Bagian ketiga kuesioner juga memasukkan 8 item skala tentang perspektif guru terhadap praktik supervisi MAN di Kudus. Kuesioner juga dibagi menjadi sisi kiri (lembar "A") dan sisi kanan (lembar "B"). Untuk setiap item, guru diminta untuk memilih, di sisi kiri, "Ya" atau "Tidak" untuk membuat deskripsi yang jelas tentang setiap pernyataan dari perspektif, dan di sebelah kanan, untuk menunjukkan seberapa sering mereka mengalaminya. perspektif saat proses supervisi di sekolah. Tanggapan di sisi kanan disusun dalam kontinum dari "Jarang" hingga "Selalu".

Tabel 3. Perspektif Guru MAN di Kudus terhadap Supervisi Efektif

\begin{tabular}{llllll}
\hline No & PERNYATAAN & A & B & Jmlh. & Pers. \\
\hline
\end{tabular}




\begin{tabular}{|c|c|c|c|c|c|c|}
\hline & $\begin{array}{l}\text { (Perspektif Guru } \\
\text { dalam supervisi) }\end{array}$ & & $\mathrm{MAN}_{1}$ & $\overline{M A N} 2$ & $\left(\sum\right)$ & $(\%)$ \\
\hline \multirow[t]{4}{*}{ a. } & \multirow{4}{*}{$\begin{array}{l}\text { Saat supervisi akan } \\
\text { dilaksanakan, guru } \\
\text { merasa gugup / } \\
\text { khawatir / takut. }\end{array}$} & Jawaban "Tidak" & 37 & 29 & 66 & 50,7 \\
\hline & & Jawaban Jarang & 11 & 15 & 26 & 20,0 \\
\hline & & Kadang & 10 & 14 & 24 & 18,5 \\
\hline & & Selalu & 2 & 12 & 14 & 10,8 \\
\hline \multirow[t]{4}{*}{ b. } & \multirow{4}{*}{$\begin{array}{l}\text { Kegiatan supervisi } \\
\text { pendidikan adalah hal } \\
\text { biasa dan rutin. }\end{array}$} & Jawaban "Tidak" & 9 & 1 & 10 & 7,7 \\
\hline & & Jawaban & 18 & 6 & 24 & 18,5 \\
\hline & & "Ya" & 26 & 31 & 57 & 43,8 \\
\hline & & Selalu & 7 & 32 & 39 & 30,0 \\
\hline \multirow[t]{4}{*}{ c. } & \multirow{4}{*}{$\begin{array}{l}\text { Pelaksanaan supervisi } \\
\text { pendidikan dapat } \\
\text { meningkatkan } \\
\text { kompetensi dan } \\
\text { profesionalisme guru. }\end{array}$} & Jawaban “Tidak” & 3 & 2 & 5 & 3,8 \\
\hline & & \multirow{3}{*}{$\begin{array}{l}\text { Jawaban } \\
\text { "Ya" }\end{array}$} & 14 & 4 & 18 & 13,9 \\
\hline & & & 29 & 19 & 48 & 36,9 \\
\hline & & & 14 & 45 & 59 & 45,4 \\
\hline \multirow[t]{4}{*}{ d. } & \multirow{4}{*}{$\begin{array}{l}\text { Kebijakan sekolah } \\
\text { memungkinkan guru } \\
\text { untuk terlibat dan } \\
\text { memilih jenis supervisi } \\
\text { yang efektif. }\end{array}$} & Jawaban "Tidak” & 6 & 6 & 12 & 9,2 \\
\hline & & \multirow{3}{*}{$\begin{array}{l}\text { Jawaban } \\
\text { "Ya" }\end{array}$} & 19 & 8 & 27 & 20,8 \\
\hline & & & 25 & 36 & 61 & 46,9 \\
\hline & & & 10 & 20 & 30 & 23,1 \\
\hline \multirow[t]{4}{*}{ e. } & \multirow{4}{*}{$\begin{array}{l}\text { Supervisi sekolah } \\
\text { biasanya berjalan } \\
\text { efektif dan tidak } \\
\text { menghadapi masalah } \\
\text { yang berarti. }\end{array}$} & Jawaban “Tidak” & 4 & 4 & 8 & 6,2 \\
\hline & & \multirow{3}{*}{$\begin{array}{l}\text { Jawaban } \\
\text { "Ya" }\end{array}$} & 24 & 8 & 32 & 24,6 \\
\hline & & & 24 & 31 & 55 & 32,3 \\
\hline & & & 8 & 27 & 35 & 26,9 \\
\hline \multirow[t]{4}{*}{ f. } & \multirow{4}{*}{$\begin{array}{l}\text { Setiap guru bisa } \\
\text { mendapatkan } \\
\text { keuntungan dari proses } \\
\text { supervisi pelaksanaan. }\end{array}$} & Jawaban "Tidak" & 4 & 4 & 8 & 6,2 \\
\hline & & \multirow{3}{*}{$\begin{array}{l}\text { Jawaban } \\
\text { "Ya" }\end{array}$} & 12 & 4 & 16 & 12,3 \\
\hline & & & 31 & 23 & 54 & 41,5 \\
\hline & & & 13 & 39 & 52 & 40,0 \\
\hline \multirow[t]{4}{*}{ g. } & \multirow{4}{*}{$\begin{array}{l}\text { Proses supervisi yang } \\
\text { dilakukan di Sekolah } \\
\text { menjadi sarana } \\
\text { kolaborasi antara guru, } \\
\text { pimpinan dan pengawas } \\
\text { madrasah. }\end{array}$} & Jawaban “Tidak” & 2 & 9 & 11 & 8,5 \\
\hline & & \multirow{3}{*}{$\begin{array}{l}\text { Jawaban } \\
\text { "Ya" }\end{array}$} & 11 & 4 & 15 & 11,5 \\
\hline & & & 35 & 21 & 56 & 43,1 \\
\hline & & & 12 & 36 & 48 & 36,9 \\
\hline \multirow[t]{4}{*}{ h. } & \multirow{4}{*}{$\begin{array}{l}\text { Proses supervisi di } \\
\text { Sekolah meningkatkan } \\
\text { rasa percaya diri dan } \\
\text { motivasi guru }\end{array}$} & Jawaban “Tidak” & 2 & 6 & 8 & 6,2 \\
\hline & & Jawaban & 10 & 5 & 15 & 11,5 \\
\hline & & Kadang & 28 & 24 & 52 & 40,0 \\
\hline & & Selalu & 20 & 35 & 55 & 42,3 \\
\hline
\end{tabular}

Dari data yang terkumpul dapat diketahui bahwa jawabannya adalah; 50,7\% jawaban "TIDAK" dan 49,3\% jawaban "YA" untuk pernyataan pertama dari perspektif guru MAN di Kudus untuk supervisi yang efektif, 7,7\% "TIDAK" dan 92,3\% "YA" untuk pernyataan kedua, 3,8\% "TIDAK" dan 96,2\% "YA" untuk pernyataan ketiga, 9,2\% "TIDAK" dan 91,8\% "YA" untuk pernyataan keempat, 
6,2\% "TIDAK" dan 93, 8\% "YA" untuk pernyataan yang kelima, 6,2\% "TIDAK" dan 93,8\% "YA" untuk pernyataan keenam, 8,5\% "TIDAK" dan 91,5\% "YA" untuk pernyataan ketujuh dan 6,2 \% "TIDAK" dan 93,8\% "YA" untuk pernyataan yang terakhir.

Di bagian keempat kuesioner, responden guru ditanyai empat item terbuka tentang model supervisi yang efektif. Item tersebut berisi tujuh model supervisi.

Tabel 4. Model Supervisi yang Efektif Berdasarkan Perspektif Guru

\begin{tabular}{|c|c|c|c|c|c|c|c|c|}
\hline \multirow{2}{*}{ Institusi } & \multicolumn{7}{|c|}{ Pilihan Model Supervisi } & \multirow{2}{*}{$\begin{array}{l}\text { Teacher's } \\
\text { Own Model }\end{array}$} \\
\hline & $\mathrm{ClS}$ & DS & $\mathrm{CnS}$ & S-R & Por & PGP & AM & \\
\hline MAN 1 & 43 & 14 & 19 & 6 & 11 & 4 & 30 & 1 \\
\hline MAN 2 & 50 & 35 & 13 & 9 & 8 & 11 & 40 & $\mathrm{O}$ \\
\hline Jmlh. $(\Sigma)$ & 93 & 49 & 32 & 15 & 19 & 15 & 70 & 1 \\
\hline Pers. (\%) & 71,5 & 37,7 & 24,6 & 11,5 & 14,6 & 11,5 & 53,8 & 0,8 \\
\hline
\end{tabular}

Catatan:

ClS : Clinical Supervision

DS : Developmental Supervision

Cns : Collaborative Supervision

S-R : Self-Reflection

Por : : Portfolios

PGP : Professional Growth Plans

AM : Administrative Monitoring

Dilihat dari tabel di atas, dapat dipahami bahwa hasil survei menunjukkan $71,5 \%$ dari 130 responden memilih "Clinical Supervision", 37,7\% memilih "Developmental Supervision", 24,6\% memilih "Collaborative Supervision", $11,5 \%$ memiliki "SelfReflection", 14,6\% memilih "Portfolios", 11,5\% memiliki "Professional Growth Plans", 53,8\% memiliki "Administrative Monitoring" dan hanya $0,8 \%$ yang memiliki "Own Model" ". Selain itu peneliti juga menemukan data berikut.

Tabel 5. Model Pengawasan Pilihan Responden

\begin{tabular}{|c|c|c|c|c|}
\hline \multirow[b]{2}{*}{ Institusi } & \multicolumn{4}{|c|}{ Model Pengawasan Pilihan Responden } \\
\hline & Hanya satu & Lebih dari satu & $\begin{array}{r}\text { Memberi } \\
\text { alasan }\end{array}$ & $\begin{array}{r}\text { Tidak } \\
\text { memberi } \\
\text { alasan }\end{array}$ \\
\hline
\end{tabular}




\begin{tabular}{|c|c|c|c|c|}
\hline $\mathrm{MAN}_{1}$ & 23 & 37 & 44 & 16 \\
\hline MAN 2 & 25 & 45 & 61 & 9 \\
\hline Jmlh. $\left(\sum\right)$ & 48 & 82 & 105 & 25 \\
\hline Pers. (\%) & 36,9 & 63,1 & 80,8 & 19,2 \\
\hline
\end{tabular}

Kemudian terkait dengan tabel tersebut peneliti mendapatkan data bahwa $36,9 \%$ responden hanya memilih satu model supervisi dan 63,1\% lebih dari satu model. Ia juga mendapatkan data bahwa $80,8 \%$ responden memberikan alasan memilih model dan 19,6\% tidak memberikan alasan. Data yang ditemukan ini melengkapi hasil survei (data kuantitatif) dari penelitian campuran ini.

Selain itu, temuan di atas diperkuat dengan hasil wawancara dengan para guru MAN yang berkompeten dalam bidang supervisi. Peneliti menemukan informasi tambahan; yakni, metode perekaman (recording) adalah metode supervisi yang paling tepat. Tapi hal ini tergantung pada sarana prasarana di lingkungan kerja, sumber daya yang tersedia serta preferensi pribadi supervisor (orang yang melakukan supervisi). Misalnya, supervisor lebih suka membuat catatan singkat (nilai, komentar, atau saran) selama proses supervisi, kemudian menulis ulang atau mengetiknya secara sistematis. Terlebih lagi, bagi beberapa supervisor, mungkin kesulitan untuk menyelesaikan laporan hasil supervisi mereka dengan segera dan lebih memilih untuk membuat catatan singkat dengan tulisan tangan selama proses supervisi. Meskipun hal ini agak mengganggu alur supervisi, seringkali supervisor memberi jeda untuk mencatat hasil atau tindak lanjut yang disepakati (antara supervisor dan guru yang disupervisi). Jeda waktu ini juga memberikan kesempatan supervisee (guru yang disupervisi) untuk mencatat dan mengkonfirmaasi hal-hal yang menjadi hasil supervisi. Kemudian, Salinan catatan diberikan kepada pengawas segera setelah selesai kegiatan supervisi.

Metode apa pun yang dipilih, penting bahwa keputusan dan tindakan utama yang disepakati dicatat dengan rentang waktu dan tanggung jawab yang jelas. Ini akan mengurangi kebingungan dan kemungkinan tindakan tidak ditindaklanjuti atau ditunda. Ini akan menjadi sama pentingnya bagi supervisee (guru yang disupervisi) untuk supervisor (orang yang melakukan supervisi) dan memperkuat keduanya. Supervisi yang baik bisa menjaga staf dan karyawan dengan suatu organisasi atau lembaga. Hal ini membuat mereka merasa bahwa ada seseorang peduli apakah mereka melakukan 
pekerjaan dengan baik atau tidak, dan bahwa ada struktur yang kokoh yang mendukung mereka jika mereka mengalami masalah. Ini adalah faktor-faktor yang membuat orang senang dengan pekerjaan mereka, dan mendorong mereka untuk bertahan.

Supervisi yang baik membentuk suatu jenis model yang harus ada di seluruh bagian organisasi. Supervisor yang memahami pekerjaannya memperlakukan semua staf dan karyawan dengan hormat, fokus pada kebutuhan profesional dan pribadi serta pengembangan kompetensi orang yang mereka awasi, dan menginspirasi antusiasme untuk pekerjaan dan loyalitas terhadap visi dan misi organisasi.

Pandangan standar tentang pengawasan, seperti yang telah kami sebutkan, seringkali negatif. Supervisor dipandang sebagai pengawas dan kritik, mungkin dengan cara yang bermusuhan terhadap pekerjaan orang yang mereka awasi. Kenyataannya, pengawasan yang efektif adalah kemitraan. Supervisor memberikan dukungan profesional dan emosional, informasi, saran, dan koneksi ke organisasi yang lebih besar (menyampaikan kekhawatiran, membantu mendapatkan persediaan dan peralatan, dll.), Dan supervisor dan orang yang supervisi bekerja bersama dan memecahkan masalah. Untuk organisasi kesehatan dan layanan masyarakat, jenis pengawasan ini masuk akal tidak hanya secara praktis, tetapi secara filosofis. Hubungan pengawasan kemitraan yang suportif mencerminkan cita-cita demokratis dan humanistik dari sebagian besar organisasi jenis ini, dan mencontohkan serta mempromosikan jenis hubungan yang harus dikembangkan oleh staf dan relawan satu sama lain dan dengan peserta program.

Pada saat yang sama, supervisor di sebagian besar organisasi memiliki tanggung jawab yang lebih dari sekedar dukungan dan nasihat. Mereka bertanggung jawab untuk memastikan supervisor mereka memiliki pengetahuan, materi, ruang, dll. Yang mereka butuhkan untuk melakukan pekerjaan dengan baik, dan mereka juga bertanggung jawab untuk memastikan pekerjaan diselesaikan dengan baik dan tepat waktu. Itulah sisi praktis dari pengawasan, dan dapat menentukan apakah organisasi mencapai tujuannya atau tidak.

Shodiya menjelaskan bahwa konseptualisasi guru dan pengawas dalam supervisi instruksional serupa dengan bagaimana mereka mengalami dan mempraktikkannya di sekolah. ${ }^{15}$ Dengan

${ }^{15}$ Tunde Gbenga Shodiya, "Models of Supervision in Education," University of Ilorin, Ilorin Nigeria, no. 1 (2005): 11. 
kata lain, konseptualisasi supervisi instruksional mereka juga dicirikan oleh kombinasi model supervisi tradisional dan kontemporer. Ketika ditanya tentang konseptualisasi supervisi instruksional mereka, guru dan supervisor mendaftar aspek dan praktik. ${ }^{16}$

Kalau proses pendidikannya sudah bagus, otomatis hasilnya mengikuti. Jika pengawas hanya fokus pada produk, pengawasan gagal. Model supervisi yang diterapkan efektif karena di sekolah guru menggunakan model kolaboratif. ${ }^{17}$ Jika guru dan pengawas berkolaborasi satu sama lain, komunikasi kita lebih baik dan waktunya mungkin tidak harus berubah lebar. Model supervisi yang efektif berjalan di MAN adalah model kolaboratif. Ia mengatakan bahwa model ini memberikan cara komunikasi yang lebih baik antara pengawas dan pengawas. Ini juga tidak membutuhkan waktu lagi. Itu tidak mengganggu jadwal mengajar guru.

\section{Simpulan}

Kesimpulan dari penelitian ini yang merupakan hasil peneliti adalah; Proses supervisi di Madrasah Aliyah Negeri (MAN) di Kudus berjalan efektif. Hal ini dibuktikan dengan hasil penelitian yang memenuhi delapan kriteria supervisi efektif yaitu 92,8\% responden menjawab efektif, kedua proses supervisi efektif menurut perspektif guru Madrasah Aliyah Negeri (MAN) di Kudus adalah positif. Pernyataan perspektif delapan guru tentang hasil supervisi yang efektif menunjukkan bahwa sebagian besar perspektif guru; $87,8 \%$ terkait pernyataan positif, dan terakhir model supervisi yang efektif terkait perspektif guru Madrasah Aliyah Negeri (MAN) di Kudus adalah "Clinical Supervision"; $71,6 \%$ dan "Administrative monitoring"; $53,8 \%$.

\section{Referensi}

Jurnal:

Manuel, Cebrián de la Serna. "Supervision Using E-Portfolios and Its Impact on Student Reflections during the Practicum: A

16 Börkur Hansen and Steinunn Helga Lárusdóttir, "Instructional Leadership in Compulsory Schools in Iceland and the Role of School Principals," Scandinavian Journal of Educational Research 59, no. 5 (September 3, 2015): 583603, https://doi.org/10.108o/o0313831.2014.965788.

${ }^{17}$ Cebrián de la Serna Manuel, "Supervision Using E-Portfolios and Its Impact on Student Reflections during the Practicum: A Case Study," University of Malaga. Faculty of Educational Sciences. Malaga, Spain., 2011, 17. 
Case Study." University of Malaga. Faculty of Educational Sciences. Malaga, Spain., 2011, 17.

Hansen, Börkur, and Steinunn Helga Lárusdóttir. "Instructional Leadership in Compulsory Schools in Iceland and the Role of School Principals." Scandinavian Journal of Educational Research 59, no. 5 (September 3, 2015): 583-603. https://doi.org/10.108o/o0313831.2014.965788.

Shodiya, Tunde Gbenga. "Models of Supervision in Education." University of Ilorin, Ilorin Nigeria, no. 1 (2005): 11.Smith, Sean. “Teacher Mentoring and Collaboration." Teacher Education Associate Editor's Column, Winter, 17, no. 1 (2020): 47-48.

Wanzare, Zachariah. "Educational Management Administration \& Leadership.” Sage Publications, Educational Management Administration \& Leadership, 40, no. 2 (March 2012): 188216.

Wanzare, Zachariah, and Jose L da Costa. "Supervision and Staff Development: Overview of the Literature." Sage Publications, Nassp Bulletin, 84, no. 618 (October 2000): 47-54.

Buku:

Creswell, John W. A Concise Introduction to Mixed Methods Research. London: SAGE, 2014.

Creswell, John W. Research Design: Qualitative, Quantitative, and Mixed Methods Approaches. 4th ed. Thousand Oaks: SAGE Publications, 2014.

Drake, Thelbert L., and William Henry Roe. The Principalship. 5th ed. Upper Saddle River, N.J: Merrill, 1999.

Eley, Adrian, and Roy Jennings. Effective Postgraduate Supervision. Maidenhead: McGraw-Hill International (UK) Ltd., 2007. https://public.ebookcentral.proquest.com/choice/publicfullr ecord.aspx? $\mathrm{p}=287816$.

Oghuvbu, Enamiroro Patrick. Determinants of Effective and Ineffective Supervision in Schools: Teachers Perspectives. Winneba, Ghana: University of Education, 2015.

Poerwadarminta, W. J. S. Kamus Umum Bahasa Indonesia. Ed. 3. Jakarta: Balai Pustaka, 2003.

Rowe, Andrea, and Jane Haywood. Providing Effective Supervision Includes Examples for Organisations and Managers to Adapt for the Development of Their Supervision Practice. A Workforce Development Tool, Including a Unit of Competence and Supporting Guidance. This publication may be copied for 
non-Commercial distribution in aid of workforce development. England: Skills for Care \& CWDC, 2007.

Sergiovanni, Thomas J. The Principalship: A Reflective Practice Perspective. Boston: Allyn and Bacon, 1987.

Sergiovanni, Thomas J., Robert J. Starratt, and Vincent Cho. Supervision: A Redefinition. Ninth Edition. New York, NY: McGraw-Hill, 2014.

Stronge, James $\mathrm{H}$. Qualities of Effective Teachers. 2nd ed. Alexandria, Va: Association for Supervision and Curriculum Development, 2007. 